\title{
Neural correlates of olfactory learning: Critical role of centrifugal neuromodulation
}

\author{
Max L. Fletcher ${ }^{1,3}$ and Wei R. Chen ${ }^{2,3}$ \\ ${ }^{1}$ Department of Anatomy and Neurobiology, University of Tennessee Health Science Center, Memphis, Tennessee 38163, USA; \\ ${ }^{2}$ Department of Neurobiology and Anatomy, University of Texas Health Science Center, Houston, Texas 77030, USA
}

\begin{abstract}
The mammalian olfactory system is well established for its remarkable capability of undergoing experience-dependent plasticity. Although this process involves changes at multiple stages throughout the central olfactory pathway, even the early stages of processing, such as the olfactory bulb and piriform cortex, can display a high degree of plasticity. As in other sensory systems, this plasticity can be controlled by centrifugal inputs from brain regions known to be involved in attention and learning processes. Specifically, both the bulb and cortex receive heavy inputs from cholinergic, noradrenergic, and serotonergic modulatory systems. These neuromodulators are shown to have profound effects on both odor processing and odor memory by acting on both inhibitory local interneurons and output neurons in both regions.
\end{abstract}

For most mammals, olfaction plays an important role in many aspects of life, such as mate attraction and recognition, motherinfant attachment, navigation, as well as detection of predators. Not surprisingly, mammals, especially rodents, have demonstrated an exceptional capability to quickly learn, remember, and discriminate odors. Past research has shown that the early stages of olfactory processing display a remarkable degree of plasticity and can play a significant role in olfactory learning. One striking feature of this system is the surprisingly large amount of centrifugal influence on odor processing in the early olfactory pathways. Both the olfactory bulb and piriform cortex receive input from multiple neuromodulatory regions releasing acetylcholine, norepinephrine, and serotonin. These neuromodulators are known to play a major role in learning-related events such as changes in arousal, attention to novel or salient stimuli, and emotional states such as stress or fear. Similar to other sensory systems, both physiological and behavioral experiments have shown that these neuromodulators can have profound effects on odor processing as well as olfactory learning and memory. Here, we focus on learning-induced plasticity in the early olfactory pathways and the role that centrifugal neuromodulation plays in facilitating this process.

\section{Experience-induced olfactory plasticity}

Experience-induced changes can be observed in all regions of the olfactory system, most work has focused on two main areas: the olfactory and piriform cortex. In these areas, experience-induced changes can be seen from the neuron population level down to molecular changes in individual cells. Globally, for example, associative conditioning can alter the levels of olfactory bulb excitatory and inhibitory neurotransmitters, as well as neuromodulators such as norepinephrine (Brennan et al. 1998). Odor-induced beta and gamma frequency local field potential oscillations in the bulb are also significantly altered following learning, again reflecting changes in global excitation and inhibition (Freeman and Schneider 1982; Ravel et al. 2003; Martin et al. 2004; Beshel et al. 2007).

\footnotetext{
${ }^{3}$ Corresponding authors.

E-mail mfletch4@uthsc.edu.

E-mail wei.r.chen@uth.tmc.edu.

Article is online at http://www.learnmem.org/cgi/doi/10.1101/Im.941510.
}

Even at the earliest stage of processing in the bulb, olfactory associative conditioning can enhance subsequent glomerular responses to experienced odorants as well as related odorants (Coopersmith and Leon 1984; Johnson et al. 1995; Yuan et al. 2002; Salcedo et al. 2005; Woo et al. 2007; Fletcher et al. 2009). Odor responses by output neurons, mitral/tufted cells, can be significantly altered with experience (Kay and Laurent 1999; Doucette and Restrepo 2008). For example, following associative conditioning in rat pups, mitral cells display more suppression to the trained odorant (Wilson and Leon 1988b). Similar results have also been observed following simple odor exposure in adults (Buonviso et al. 1998; Buonviso and Chaput 2000; Fletcher and Wilson 2003).

Odor learning can alter inhibitory neuron activity as well. Several studies have shown changes in granule cell immediate early gene expression following both associative conditioning (Woo et al. 1996; Funk and Amir 2000) and odor enrichment (Montag-Sallaz and Buonviso 2002; Mandairon et al. 2008a). Adult granule cell neurogenesis and survival can also be affected by experience, as olfactory enrichment has been shown to decrease granule cell death (Woo et al. 2006) and increase the number of newly formed granule cells (Rochefort et al. 2002).

Olfactory experience can lead to physiological and anatomical changes in piriform cortex as well. For example, olfactory discrimination rule learning has been shown to enhance synaptic transmission of mitral cell input onto cortical pyramidal cells as well as association input from other pyramidal cells (Roman et al. 1987; Litaudon et al. 1997; Saar et al. 2002; Cohen et al. 2008). Pyramidal cells also display reduced afterhyperpolarization following the same learning tasks, suggesting enhanced excitability (Saar et al. 2002). Additionally, learning also leads to increased inhibition of pyramidal cell activity (Brosh and Barkai 2009). These physiological changes are accompanied by structural changes as well, with learning modifying the structure of pyramidal cell dendritic spines (Knafo et al. 2001).

\section{Neural correlates of plasticity}

Although learning-induced plasticity can occur throughout the olfactory system, there appear to be mechanisms in place to drive plasticity even at the first synapse. For example, in vitro work has shown the receptor neuron-to-mitral cell synapses 
within each glomerulus are capable of undergoing long-term potentiation (LTP) (Ennis et al. 1998). Similar to LTP in other systems, the plasticity involves the activation of NMDA receptors located on mitral/tufted cell dendrites (Ennis et al. 1998). In this case, mitral cells displayed prolonged, increased spiking following high frequency olfactory nerve stimulation. Alternatively, this same synapse has also been shown to display the opposite effect, long-term depression (LTD) (Mutoh et al. 2005). Here, low frequency stimulation of the olfactory nerve resulted in a decrease in receptor neuron transmitter release onto mitral cells. This effect was found to be mediated by metabotropic glutamate receptors most likely located on the receptor neuron axon terminals (Mutoh et al. 2005). Together these results show that even the first synapse into the bulb is capable of experience-induced plasticity and could serve as an initial site for odor memory formation.

Another potential mechanism of olfactory bulb plasticity involves altering the activity levels of inhibitory interneurons. Within the bulb, there are two populations of intrinsic neurons that provide inhibitory input onto output neurons. At the glomerular level, afferent input onto mitral cells is modulated by periglomerular cells. These cells can affect receptor neuron synaptic transmission by suppressing transmitter release from presynaptic terminals as well as provide inhibition onto neurons postsynaptic to receptor neuron input (Aroniadou-Anderjaska et al. 2000; Aungst et al. 2003; Murphy et al. 2005; Wachowiak et al. 2005; Vucinic et al. 2006). Deeper in the bulb, another population of inhibitory neurons, granule cells, form reciprocal dendrodendritic synapses with the lateral dendrites of mitral cells (Shepherd et al. 2004). These synapses are important for controlling both feedback inhibition onto the same mitral cell and lateral inhibition of other mitral cells (Jahr and Nicoll 1982; Yokoi et al. 1995; Isaacson and Strowbridge 1998; Chen et al. 2000; Arevian et al. 2008).

Pyramidal cells in the piriform cortex receive direct excitatory input from $\mathrm{M} / \mathrm{T}$ cell axons from the bulb. In addition they also receive excitatory input from other cortical pyramidal cells via an extensive association fiber system (Haberly 2001). Both of these synapses have been shown to be capable of long-term plasticity. For example, LTP can be induced in both afferent and association fiber synapses (Stripling et al. 1988; Jung et al. 1990; Kanter and Haberly 1990; Roman et al. 1993a). As with olfactory bulb LTP, both pathways are dependent upon activation of NMDA receptors (Kanter and Haberly 1990). Alternatively, LTD has also been demonstrated at the association fiber to pyramidal cell synapse and was found to be dependent upon metabotropic glutamate receptors (Young and Sun 2007).

Interestingly, these circuits, both in the bulb and piriform cortex, are subject to heavy centrifugal input from fibers originating in several different neuromodulatory regions. In all cases, these fibers can directly influence both inhibitory and output cell activity and are poised to shape odor responses via topdown influence based on the state or attention level of the animal. Consequently, several studies have shown that centrifugal modulation plays a major role in many forms of olfactory learning.

\section{Acetylcholine}

Cholinergic modulation has been correlated with attention, learning, and memory in several systems (Bear and Singer 1986; Blokland 1995; Weinberger and Bakin 1998; Hasselmo 1999). In the olfactory system, the cholinergic modulation has been implicated in several types of learning including habituation, social recognition, associative conditioning, delayed-match-to-sample, rule learning, and perceptual learning.

\section{Role of $\mathrm{ACh}$ in olfactory learning}

Several studies have demonstrated olfactory learning impairments when acetylcholine input is blocked or reduced (although, see Wirth et al. 2000). For example, cholinergic release appears to be necessary for olfactory short-term memory, such as in the case of habituation to novel odorants. In this case, both cholinergic lesions and systemic muscarinic antagonists were found to block habituation to repeated odorant presentations (Hunter and Murray 1989; Paolini and McKenzie 1993; Miranda et al. 2009). Blocking cholinergic action in social habituation paradigms causes similar impairments as injections of muscarinic antagonists impair habituation to odors from conspecific juveniles or females (Perio et al. 1989; Winslow and Camacho 1995). Together, these studies highlight the importance of muscarinic activation in olfactory memory acquisition. However, since the cholinergic manipulations were global, it is difficult to determine from these studies which olfactory structures were affected. However, a recent study reported that direct infusion of both nicotinic and muscarinic antagonists into the olfactory bulb had no effect on odor habituation suggesting that the site of ACh action may be in higher olfactory areas (Mandairon et al. 2006).

In another test of short-term memory, systemic injections of the muscarinic antagonist scopolamine blocked odor memory in an olfactory delayed match to sample task (Ravel et al. 1992). Additionally, direct infusion of scopolamine into the bulb gave similar results, suggesting that muscarinic activation of olfactory bulb circuits were necessary for memory formation (Ravel et al. 1994). Similarly, rats with cholinergic lesions displayed deficits in learning odor-reward associations in a successive cue discrimination task, especially when the intertrial interval was increased (Roman et al. 1993b).

Acetylcholine also plays an important role in learning odor associations as well. For example, scopolamine blocked ewe's learning of lamb odor, but had no effect on recognition if administered following learning (Levy et al. 1997). A recent study using an odor-fear conditioning paradigm showed that blocking acetylcholine impaired the acquisition of an odor-shock association. In this case, injection of scopolamine prior to training caused animals to display less defensive responses to the conditioned odor following training (Kroon and Carobrez 2009). Additionally, in an olfactory discrimination set learning task, muscarinic blockers impaired learning of the initial discrimination pair, with no affect on the learning of subsequent pairs, again highlighting ACh's role in acquisition (Saar et al. 2001).

In a more complex task, acetylcholine was also found to be important for learning subsequent associations. Both scopolamine injected rats and HDB lesioned rats displayed impairments in learning when a component of an odor-association pair that signaled reward $(\mathrm{A}+, \mathrm{B}-)$ in a previous discrimination task was presented in a new odor-association discrimination task with a different reward odor (A-,C+) (De Rosa and Hasselmo 2000; De Rosa et al. 2001). In this case, ACh was proposed to work to reduce interference between previously learned odors with overlapping components.

Finally, acetylcholine has recently been shown to be an important modulator of olfactory perceptual learning. In perceptual learning, previous experience increases subsequent acuity or discrimination of the experienced stimulus. In this case, the representation of the previously experienced stimulus is thought to be enhanced in a way that reduces the overlap between it and similar stimuli. For example, following conditioning, rats are capable of discriminating two similar monomolecular odorants that were indiscriminable in naïve animals (Fletcher and Wilson 2002; Linster et al. 2002). This effect could be blocked by the application of scopolamine during training (Fletcher and Wilson 2002). 
Overall, results from several different learning paradigms provide strong evidence that $\mathrm{ACh}$ is required for olfactory learning and memory. Interestingly, studies focusing on spontaneous discriminations that do not require the animal to learn any behavioral tasks have demonstrated that blocking cholinergic modulation can disrupt discrimination of novel, structurally similar odorants (Linster et al. 2001; Mandairon et al. 2006). Taken together, these studies suggest that anACh release into the olfactory system during learning situations may serve multiple purposes; initially enhancing the representation of the salient odor while at the same time causing long-term changes in the circuitry representing that odor.

\section{ACh action in the olfactory bulb}

The vast majority of cholinergic input into the olfactory bulb comes from the horizontal limb of the diagonal band of Broca (HDB) (Shute and Lewis 1967; Macrides et al. 1981; Luskin and Price 1982; Carson 1984; Woolf et al. 1984; Zaborszky et al. 1986; Wright and Fitzgerald 2001). In rodents, HDB fibers are found throughout the different layers of the olfactory bulb, with the heaviest projections to the glomerular layer and internal plexifom layer (Ichikawa and Hirata 1986; Kasa et al. 1995; Gomez et al. 2005). In these regions, cholinergic fibers synapse onto interneurons, primarily periglomerular cells and granule cells (Nickell and Shipley 1988a; Le Jeune and Jourdan 1993; Kasa et al. 1995). The HDB also receives olfactory input and its activity can be modulated by both olfactory bulb and piriform cortex stimulation (Broadwell 1975; Linster and Hasselmo 2000).

Numerous studies have demonstrated a variety of effects of acetylcholine on olfactory bulb neuronal responses. At the glomerular level, acetylcholine appears to mainly affect periglomerular cell activity. For example, a recent study found that activation of muscarinic receptors could inhibit activity in dopaminergic periglomerular (PG) cells (Pignatelli and Belluzzi 2008) that provide presynaptic inhibition back onto olfactory receptor neuron (ORN) terminals (Ennis et al. 2001). In this case, cholinergic activation is thought to release olfactory receptor neuron terminals from feedback inhibition, leading to increased excitatory input into activated glomeruli. However, nicotinic receptor activation in the same region has been shown to have the opposite effect, causing excitation in some PG cells; leading to an increase in inhibition of ORN driven excitation (Castillo et al. 1999). Similar results have also been observed in vivo with the application of acetylcholine causing both excitation and inhibition in glomerular layer neurons (Ravel et al. 1990).

Similar to the glomerular layer, the effects of cholinergic modulation are complex and seem to involve multiple cell types. For example, initial studies in rabbits found that while direct application of ACh increased the spontaneous activity in a small percentage of olfactory bulb neurons, the majority displayed suppressed spontaneous activity (Bloom et al. 1964). Although the cell types were not identified, it is presumed that the suppressed cells were mitral cells, as a more recent study reported similar decreases in the spontaneous discharge of identified mitral cells following HDB stimulation (Nickell and Shipley 1988b). Based on HDB-evoked olfactory bulb field potential responses, it was concluded that this depression of mitral cell activity was a result of ACh's action on bulbar interneurons (Nickell and Shipley 1988b). In line with this, in vitro studies focusing on granule activity have shown that application of ACh agonists at relatively low concentrations can increase granule cell excitability and increase GABA release from granule-mitral cell dendrodendritic synapses through the activation of muscarinic receptors located on granule cells (Ghatpande et al. 2006; Pressler et al. 2007).
However, another study using higher concentrations of the same muscarinic agonist, carbachol, reported seemingly opposite effects. In this case, the application of carbachol lead to a decrease in granule cell spontaneous firing rates suggesting that ACh could also act to reduce granule cell-mediated feedback and lateral inhibition (Castillo et al. 1999). Two additional in vivo studies have also reported similar effects with both HDB stimulation and application of cholinergic agonists leading to reduced granule cell inhibition of mitral cell activity (Elaagouby et al. 1991; Kunze et al. 1991).

The different effects observed by the different studies may be evidence of a much more complex circuit in which ACh also activates other granule cell layer interneurons, such as excitatory interneurons or GABAergic Blanes cells (Nickell and Shipley 1988b; Pressler and Strowbridge 2007). However, while not fully reconciled, the conflicting reports of cholinergic action in the olfactory bulb all point to the fact that acetylcholine can directly affect granule and periglomerular excitability, which ultimately leads to changes in mitral cell output responses.

Based on this, modeling studies have shown that the cholinergic modulation could serve to increase lateral inhibition and reduce the overlap between bulbar odor representations, especially those evoked by similar odorants (Linster and Cleland 2002). More support for this comes from a recent study showing that mitral cell odor receptive fields can be sharpened by enhanced levels of bulbar acetylcholine (Chaudhury et al. 2009). Presumably this contrast enhancement during learning gives rise to long-term changes within the bulb circuit representing the learned odor and leads to the greater discriminability of that odor during subsequent exposures.

\section{ACh action in the piriform cortex}

Cholinergic fibers arising in the HDB also project into the pirform cortex, with the densest projection being to layers II and III (Luskin and Price 1982; Woolf et al. 1984; Lysakowski et al. 1989). Similar to the olfactory bulb, the effects of acetylcholine on piriform cortex activity are complex and mediated by different cell types. For example, acetylcholine has been shown to depolarize pyramidal cells as well as interneurons (Tseng and Haberly 1989; Barkai and Hasselmo 1994). Stimulation of the HDB also leads to increased pyramidal cell spontaneous activity, suppression of association fiber input onto pyramidal cells, and enhanced LOT fiber transmission (Hasselmo and Bower 1992; Linster et al. 1999; Zimmer et al. 1999). Muscarinic activation also leads to a reduction in pyramidal cell firing adaptation and after hyperpolarization (Constanti and Sim 1987; Barkai and Hasselmo 1994; Saar et al. 2001). Acetylcholine can also enable LTP of association fiber synapses (Hasselmo and Barkai 1995; Patil et al. 1998).

These studies show that acetylcholine release during learning or attention leads to both short- and long-term modification in the strength of association fiber input onto pyramidal cells in the piriform cortex. According to modeling studies, the initial suppression of the association fiber input during learning and the subsequent enhancement of this input serve to sharpen the representation of the learned odorant and reduce the overlap of similar odor representations (Hasselmo and Barkai 1995; Linster and Hasselmo 2001). Both physiological and behavioral evidence exists to support this idea. For example, scopolamine increases the generalization of odor responses in anterior piriform cortex neurons (Wilson 2001). Behaviorally, manipulation of acetylcholine can alter odor discrimination as well. Lesions of the HDB caused rats to generalize their responses to other odors similar to the trained odor in an odor-reward task (Linster et al. 2001; Linster and Cleland 2002). Alternatively, application of cholinergic agonists or acetylcholinesterase inhibitors has been shown to 
enhance odor discrimination in rats (Doty et al. 1999; Mandairon et al. 2006).

\section{Norepinephrine}

The noradrenergic system is known to play an important role in arousal, attention and emotional state (Wilson and Sullivan 1994; Berridge and Waterhouse 2003; Sara 2009). Increased locus coeruleus activity and norepinephrine release have also been correlated with processing of novel stimuli, learned fear, as well as social events such as mating and mother-infant interactions (Levy et al. 1990; Aston-Jones et al. 1991; Sara et al. 1994; Wilson and Sullivan 1994; Keverne and Brennan 1996; Ishida et al. 2002). In the main olfactory system, the noradrenergic system has been implicated in several types of learning, including infant attachment, nonassociative and associative conditioning, and habituation.

\section{Role of NE in mother-infant attachment}

NE release into the olfactory bulb has been shown to be important for olfactory associative learning during sensitive periods (Kendrick et al. 1992; Rangel and Leon 1995). Blocking the action of NE in the bulb via infusion of the $\beta$ antagonist propranolol blocks the acquisition of lamb odor in post-parturient ewes (Levy et al. 1990). Similarly in rat pups, both LC lesions and infusion of propranolol into the olfactory bulb block the acquisition of an odor preference (Sullivan et al. 1989; 1992). Furthermore, additional studies have demonstrated that pairing injection or bulb infusion of $\alpha$ or $\beta$ agonists with odor presentation alone is sufficient to induce an odor preference in pups (Sullivan et al. 2000; Harley et al. 2006). Together these results provide strong evidence that action of $\mathrm{NE}$ alone in the bulb can serve as the unconditioned stimulus in pup olfactory associative conditioning.

For pup learning, the site of NE action in the bulb is thought to be both mitral cells and granule cells as both express $\beta$ adrenoreceptors (Yuan et al. 2003a). The mechanism behind the $\beta$ receptor-mediated learning involves changes in mitral cell activity as evidenced by increased responses to olfactory nerve input (Yuan et al. 2000), as well as increased levels of cAMP in mitral cells (Yuan et al. 2003b). Additionally, NE acting on $\beta$ receptors can disinhibit mitral cells via suppression of granule cell activity (Wilson and Leon 1988a; Wilson and Sullivan 1992). Thus, the release of NE during odor learning plays a major role in the acquisition of an odor preference in rat pups and serves to induce longterm changes in the MC-GC circuit encoding the learned odor.

\section{Role of NE in adult learning}

Compared to neonates, less is known about the function of NE release in the adult olfactory system. However, several studies have demonstrated that it may serve similar purposes in adult learning. For example, both repeated, novel odorant exposure and associative conditioning lead to increased NE in the olfactory bulb (Brennan et al. 1998; Veyrac et al. 2009). Similar to neonates, increased NE paired with an odor is sufficient to induce an odor memory, even when the pairing is done in anesthetized animals (Shea et al. 2008). The major difference being that this paradigm in adults lead to the animal treating the paired odor only as if it was a familiar odor, while LC stimulation paired with an odor in young pups induces a strong odor preference (Sullivan et al. 2000). This difference in response to the learned odor between neonates and adults is thought to be a result of developmental differences in LC noradrenergic output (Moriceau and Sullivan 2004).

In addition to a role in memory acquisition, NE also affects odor detection and discrimination. For example, bulbar infusions of a combination of $\alpha$ and $\beta$ adrenoreceptor antagonists impaired the ability of mice to discriminate perceptually similar odorants, while having no effect on the initial learning of the go/no-go task (Doucette et al. 2007). Interestingly, this required blocking both $\alpha$ and $\beta$ receptors, as blocking either receptor type alone had no effect (Doucette et al. 2007). Similarly, infusions of $\alpha$ and $\beta$ antagonists together have been shown to slow acquisition of a reward-motivated odor discrimination task (Mandairon et al. 2008b). Finally, blocking $\alpha$ receptors in the bulb have been shown to impair spontaneous discrimination and detection in a task that does not require any training (Escanilla et al. 2010). Together, these studies show that NE action in the adult bulb may serve to increase acuity for odors during learning situations by enhancing both odor detection and discrimination.

In situations requiring short-term memory, such as habituation to repeated odorant presentations, the role of NE is less clear with different studies reporting seemingly conflicting results. For example, recent studies using rats found that infusion of either $\alpha$ or $\beta$ receptor antagonists had no effect on habituation to repeated odorant presentations (Mandairon et al. 2008b; Escanilla et al. 2010). However, rats with pharmacological lesions of the LC were not able to habituate to repeated odorant presentations. In these animals, normal habituation could be restored if NE was infused into the olfactory bulb (Guerin et al. 2008). The differences in these two studies are possibly due to the differences in techniques used to inhibit NE activity (neurotoxins vs. antagonists) and further study is required to fully elucidate NE's role in odor habituation.

While the function of NE in facilitating habituation is still unclear, recent work has shown that NE release is important in reversing or blocking olfactory habituation (Smith et al. 2009). In this case, NE released following a novel or unexpected stimulus can lead to dishabituation via $\beta$ receptor-mediated blocking of synaptic depression of input onto piriform cortex (Best and Wilson 2004).

\section{NE action in the olfactory bulb}

The olfactory bulb receives heavy noradrenergic input from the locus coeruleus (Macrides et al. 1981; Shipley et al. 1985). Unlike cholinergic projections from the HDB, there is only a relatively weak projection into the glomerular layer. By contrast, the densest NE projection is in the IPL and GCL (McLean et al. 1989; Gomez et al. 2005). Given the laminar specificity, it has been hypothesized that noradrenergic fibers synapse primarily onto GCs (McLean et al. 1989). While the input is not evenly distributed, both $\alpha$ and $\beta$ receptors are expressed in all layers of the bulb (Pieribone et al. 1994; Woo and Leon 1995).

Similar to acetylcholine, several studies have reported a variety of neuronal effects with the bulb in response to noradrenergic stimulation. For example, early in vivo studies using rabbits demonstrated a suppression of mitral spontaneous activity when NE agonists were applied near the cell (Bloom et al. 1964; Salmoiraghi et al. 1964; McLennan 1971). It was concluded that the main effect of NE was to enhance granule cell inhibition onto mitral cells. However, these studies only focused on spontaneous activity and did not look at odor responses.

A more recent study also found similar reductions in mitral cell spontaneous activity when the LC was stimulated (Jiang et al. 1996). However, these same cells showed increased firing rates to perithreshold sensory neuron stimulation following LC stimulation, suggesting that NE can enhance mitral cell responses to weak input (Jiang et al. 1996). Subsequent in vitro work has shown that the effect is likely mediated via direct excitation of mitral cells via $\alpha 1$ receptors (Ciombor et al. 1999; Hayar et al. 2001). Results obtained from dissociated olfactory bulb cultures have also shown that NE acting through $\alpha$ receptors can also 
enhance mitral cell excitability indirectly. In this case, NE presynaptically inhibited mitral cell-mediated granule cell excitation via $\alpha 2$ receptors, leading to mitral cell disinhibition (Trombley and Shepherd 1992).

In addition to its effects on mitral cells, NE can also directly affect granule cell excitability as well. For example, $\alpha 1$ receptor activation has been shown to increase granule cell excitability as well as increase GABA release from granule cells back onto mitral cells resulting in increased feedback inhibition (Mouly et al. 1995; Araneda and Firestein 2006; Nai et al. 2010).

Together these studies provide a seemingly contradictory picture of NE action in the bulb, whereby noradrenergic activation can simultaneously alter the excitability of both mitral and granule cells. However, recent, detailed in vitro studies has shown that the differing effects observed are a consequence of both the NE concentration and the receptor subtype involved (Nai et al. 2009 , 2010). For example, at low concentrations, NE primarily affects $\alpha 2$ receptors and serves to reduce granule cell inhibition onto mitral cells (Nai et al. 2009, 2010; Pandipati et al. 2010). Alternatively, at higher concentrations NE activates $\alpha 1$ receptors and increases the granule cell inhibitory drive onto mitral cells leading to increased mitral cell inhibition (Nai et al. 2009, 2010).

In addition to immediate effects on mitral cell inhibition, NE activation can also have longer-lasting effects as well. Olfactory nerve stimulation in vitro in the presence of NE agonists can cause long-lasting depolarization in mitral cells and enhance evoked gamma frequency oscillations in vitro (Gire and Schoppa 2008; Pandipati et al. 2010). Pairing odor presentations with LC stimulation in vivo caused long-lasting suppression of mitral cell odor responses to the paired odor with the effect blocked by application of a combination of $\alpha$ and $\beta$ receptor antagonists (Shea et al. 2008).

Overall, the main effect of NE in the bulb appears to be on the mitral-granule dendrodendritic interactions. Depending on the state of the animal, the intensity of NE, and the location of its action within the bulb, NE can play an important role in not only odor detection, but long-term changes in circuit that results in odor learning. Thus, in situations where the animal encounters a novel or potentially important stimulus, the release of NE in the bulb during odor stimulation may serve multiple purposes. First, weak sensory input could be enhanced through potentiation of mitral cell responses leading to increased odor detection and discrimination of relevant odors. Second, NE input could also work to alter the excitatory/inhibitory balance of mitral cell-granule cell feedback loops, possibly leading to LTP-like mechanisms at mitral cell-granule cell reciprocal synapse (Sullivan et al. 1992; Brennan and Keverne 1997). This would serve to facilitate GC inhibition onto MCs responding to the learned odorant after learning. This is consistent with both the decreased responses to the learned odorant observed in neonates (Wilson and Leon 1988a,b; Sullivan et al. 1992) and increased levels of GABA following learning (Kendrick et al. 1992; Brennan et al. 1995).

\section{NE action in the piriform cortex}

As with the olfactory bulb, noradrenergic fibers from the LC also project to the piriform cortex (Fallon and Moore 1978; Loughlin et al. 1982; Datiche and Cattarelli 1996; Shipley and Ennis 1996). Within the PC, NE fibers appear to have an uneven laminar distribution, with denser labeling in layers I and III (Shipley and Ennis 1996). In vitro electrophysiological studies have also highlighted NE effects on the cells of this region. For example, application of NE was found to increase the firing rate of a subpopulation of serotonin sensitive layer II/III interneurons, as well as increase GABAergic inhibitory potentials in many layer II pyramidal cells (Gellman and Aghajanian 1993; Marek and Aghajanian 1996).
As with the bulb the effects of NE appear to be concentrationdependent, with lower NE concentrations enhancing cortical responses to mitral cell input and suppressing cortical responses at higher concentrations. For example, at low concentrations $\mathrm{NE}$ enhanced mitral cell excitatory transmission onto cortical pyramidal cells either through increased transmitter release or increased pyramidal cell excitability. While at higher concentrations, excitatory release is depressed (Collins et al. 1984). Similarly, electrical stimulation of the LC in vivo leads to enhanced odor responses in PC neurons (Bouret and Sara 2002).

In addition to enhancing responses to afferent input, NE also appears to affect excitatory association fiber input onto pyramidal cells. In this case, NE application was found to decrease excitatory transmission between pyramidal cells, while having little effect on afferent LOT input (Hasselmo et al. 1997). Computational modeling of this effect has demonstrated that suppressing excitatory transmission between pyramidal cells can serve to increase the signal-to-noise ratio of afferent odor input (Hasselmo et al. 1997).

Thus, the function of NE input into the PC appears to be similar to that of ACh. Both may work together during learning to increase the strength of afferent input relative to intrinsic fiber input, which could help facilitate the learning of new odor representations within the cortex without interference from previously stored representations (Hasselmo 1995; Linster and Hasselmo 2001).

\section{Serotonin}

The serotonergic system has been implicated in modulating a variety of behaviors including stress and anxiety, sleep-wake cycles, as well as learning and memory (Lowry et al. 2005; King et al. 2008; Monti and Jantos 2008). In the olfactory system, serotonergic activation plays an important role in associative conditioning and short-term memory.

\section{Role of 5HT in neonatal learning}

In neonatal rats, serotonergic release into the olfactory bulb has been shown to be important for odor preference learning. For example, depletion of serotonergic input into the bulb or direct injection of a 5HT2 (seratonin) receptor antagonist into the olfactory bulb can block the acquisition of an odor preference (McLean et al. 1993, 1996). Although important for learning, serotonin alone may not be enough to induce memory formation as 5HT depleted pups can still form an odor preference if the noradrenergic system is pharmacologically activated (Langdon et al. 1997). Recent work suggests that the role of 5HT in neonatal learning may be to facilitate the role of NE in increasing mitral cell camp, which can lead to long-term changes in MC responses (Yuan et al. 2003b).

\section{Role of $5 \mathrm{HT}$ in adult learning}

In contrast to neonates, the role of $5 \mathrm{HT}$ in adult olfactory learning has received much less attention. A single study in which 5HT fiber input into the olfactory bulb was reduced reported impairments in adult rats' abilities to discriminate previously learned odorants (Moriizumi et al. 1994). While this study suggests that $5 \mathrm{HT}$ in the bulb is important for odor discrimination, its effect on adult olfactory learning is far from understood.

Some evidence does exist supporting the necessity of 5HT in olfactory learning, however, although the focus was only on the role of 5HT4 receptors. In this case, systemic injections of 5HT4 antagonists have been shown to impair learning of an olfactory go/no-go task, while injections of 5HT4 agonists enhanced 
learning of the same task (Marchetti et al. 2000). Similarly, systemic application of 5HT4 agonists has also been shown to enhance olfactory short-term memory in a social recognition task (Letty et al. 1997). Importantly, these studies manipulated 5 HT4 receptor activation globally, and thus the site of 5HT action in these cases is not known. Behavioral studies involving manipulation of different $5 \mathrm{HT}$ receptor subtypes, specifically in the bulb and cortex, are needed before a clearer picture of the role of 5HT in adult learning is available.

\section{HT action in the olfactory bulb}

The olfactory bulb receives serotonergic input from the dorsal and median raphe nuclei (de Olmos et al. 1978; Macrides et al. 1981; Shipley and Adamek 1984; McLean and Shipley 1987). While raphe fibers can be found in all layers of the bulb, the heaviest projection is to glomerular layer (GL) where they synapse on periglomerular cells (Halasz et al. 1978; McLean and Shipley 1987). In addition to containing the highest density of 5HT fibers, the glomerular layer also contains primarily larger fibers with more varicosities suggesting that the GL may be the primary site for 5HT modulation (McLean and Shipley 1987; Gomez et al. 2005). Interestingly, the fiber projections within the GL also appear to be heterogeneous, with dorsal glomeruli receiving heavier innervations than glomeruli located more laterally (Gomez et al. 2005).

Despite the heavy input into the bulb, there have been relatively few studies on the effects of serotonin on olfactory bulb neurons. An early study in rabbits found that iontophorectic application of $5 \mathrm{HT}$ into the bulb reduced the spontaneous discharge of mitral cells (Bloom et al. 1964). However, a more recent in vitro study has demonstrated mixed effects. In this case, 5HT was found to directly depolarize some mitral cells via 5-HT2A receptors, while hyperpolarizing others via GABA-mediated inhibition (Hardy et al. 2005). The same study also found that 5HT excited some juxtaglomerular (JG) cells as well. Finally, a recent in vivo imaging study has shown that LC stimulation, as well as bulbar application of serotonin, can excite a subset of GABAergic periglomerular cells that provide presynaptic feedback inhibition onto olfactory receptor axons (Petzold et al. 2009). In this case, serotonergic activation served to reduce the gain of sensory input into the olfactory bulb.

As with other centrifugal modulators, 5HT appears to affect mitral cell output both directly and indirectly through the activation of inhibitory interneurons. In this case, 5HT could alter mitral cell odor responses by reducing the strength of afferent input onto mitral cell via glomerular level feedback inhibition, reducing output via granule cell-mediated inhibition, or by direct depolarization. Presumably, as with NE, the specific effect of 5HT is dependent on the concentration and cell type involved.

\section{HT action in the piriform cortex}

In addition to the olfactory bulb, the raphe nuclei also project heavily to the piriform cortex (De Olmos and Heimer 1980; Datiche et al. 1995). The fiber distribution appears heavier in the anterior portion of the PC as compared with the posterior. As with NE, there also appears to be some laminar specificity as 5HT fibers are the densest in layers I and III (Datiche et al. 1995). Both 5HT1 and 5HT2 receptors are present in the PC and are mainly distributed in the deeper layers (Pompeiano et al. 1992, 1994).

As with the bulb, the effects of 5HT can be both excitatory and inhibitory depending on the receptor activated and cell type involved. For example, 5HT can directly excite pyramidal cells via 5HT1c receptors (Sheldon and Aghajanian 1991). Additionally, 5HT can increase the firing rate of a subpopulation of layer II/III inhibitory interneurons causing increased IPSPs in nearby pyramidal cells (Sheldon and Aghajanian 1990; Gellman and Aghajanian 1993). While the role that serotonergic modulation plays in olfactory learning within the PC is not known, given its overlap in input and similar physiological effects as NE, it is possible that $5 \mathrm{HT}$ might serve a similar role in enhancing the signal-to-noise ratio of odor input.

\section{Conclusions}

The early olfactory centers receive heavy innervation from three major neuromodulatory regions in the mammalian brain. While some differences occur in their input patterns into the bulb and piriform cortex, they share common neuronal targets in both regions. In all three cases, the main effect of these modulators appears to be to alter the balance of excitation/inhibition within the circuit and to shape odor responses via top-down influence based on the state or attention level of the animal.

Despite the conflicting reports, a picture is emerging where neuromodulators released into the bulb can both directly and indirectly mediate mitral cell responses. By controlling inhibitory neuron excitability in the bulb, these neuromodulators can serve to place the bulb in a learning state by increasing signal-to-noise ratios, enhancing contrast of similar odor representations, and inducing long-term changes in mitral cell responses through intracellular signaling cascades known to be important in memory storage.

At the same time, the same neuromodulators also affect the piriform cortex by increasing pyramidal cell excitability and response to afferent input while exciting deeper inhibitory interneurons. These actions are thought to place the cortex into a learning state where the strength of afferent mitral cell input is enhanced, while intrinsic fiber input onto pyramidal cells is suppressed (Hasselmo 1995). Together the combination of enhanced mitral cell response and cortical sensitivity to this input allows for long-term changes in both regions that form the basis of olfactory memory.

\section{Acknowledgments}

This work was supported by NIH grants (DC003918 and DC009666 to W.R.C.; DC009853 to M.L.F.).

\section{References}

Araneda RC, Firestein S. 2006. Adrenergic enhancement of inhibitory transmission in the accessory olfactory bulb. J Neurosci 26: 3292-3298.

Arevian AC, Kapoor V, Urban NN. 2008. Activity-dependent gating of lateral inhibition in the mouse olfactory bulb. Nat Neurosci 11: $80-87$.

Aroniadou-Anderjaska V, Zhou FM, Priest CA, Ennis M, Shipley MT. 2000. Tonic and synaptically evoked presynaptic inhibition of sensory input to the rat olfactory bulb via GABA(B) heteroreceptors. J Neurophysiol 84: $1194-1203$.

Aston-Jones G, Chiang C, Alexinsky T. 1991. Discharge of noradrenergic locus coeruleus neurons in behaving rats and monkeys suggests a role in vigilance. Prog Brain Res 88: 501-520.

Aungst JL, Heyward PM, Puche AC, Karnup SV, Hayar A, Szabo G, Shipley MT. 2003. Centre-surround inhibition among olfactory bulb glomeruli. Nature 426: 623-629.

Barkai E, Hasselmo ME. 1994. Modulation of the input/output function of rat piriform cortex pyramidal cells. J Neurophysiol 72: 644-658.

Bear MF, Singer W. 1986. Modulation of visual cortical plasticity by acetylcholine and noradrenaline. Nature 320: $172-176$.

Berridge CW, Waterhouse BD. 2003. The locus coeruleus-noradrenergic system: Modulation of behavioral state and state-dependent cognitive processes. Brain Res Brain Res Rev 42: 33-84.

Beshel J, Kopell N, Kay LM. 2007. Olfactory bulb gamma oscillations are enhanced with task demands. J Neurosci 27: 8358-8365.

Best AR, Wilson DA. 2004. Coordinate synaptic mechanisms contributing to olfactory cortical adaptation. J Neurosci 24: 652-660.

Blokland A. 1995. Acetylcholine: A neurotransmitter for learning and memory? Brain Res Brain Res Rev 21: 285-300. 
Bloom FE, Costa E, Salmoiraghi GC. 1964. Analysis of individual rabbit olfactory bulb neuron responses to the microelectrophoresis of acetylcholine, norepinephrine and serotonin synergists and antagonists. J Pharmacol Exp Ther 146: 16-23.

Bouret S, Sara SJ. 2002. Locus coeruleus activation modulates firing rate and temporal organization of odour-induced single-cell responses in rat piriform cortex. Eur J Neurosci 16: 2371-2382.

Brennan PA, Keverne EB. 1997. Neural mechanisms of mammalian olfactory learning. Prog Neurobiol 51: 457-481.

Brennan PA, Kendrick KM, Keverne EB. 1995. Neurotransmitter release in the accessory olfactory bulb during and after the formation of an olfactory memory in mice. Neuroscience 69: 1075-1086.

Brennan PA, Schellinck HM, de la Riva C, Kendrick KM, Keverne EB. 1998 Changes in neurotransmitter release in the main olfactory bulb following an olfactory conditioning procedure in mice. Neuroscience 87: $583-590$.

Broadwell RD. 1975. Olfactory relationships of the telencephalon and diencephalon in the rabbit. II. An autoradiographic and horseradish peroxidase study of the efferent connections of the anterior olfactory nucleus. J Comp Neurol 164: 389-409.

Brosh I, Barkai E. 2009. Learning-induced enhancement of feedback inhibitory synaptic transmission. Learn Mem 16: 413-416.

Buonviso N, Chaput M. 2000. Olfactory experience decreases responsiveness of the olfactory bulb in the adult rat. Neuroscience $\mathbf{9 5}$ : $325-332$.

Buonviso N, Gervais R, Chalansonnet M, Chaput M. 1998. Short-lasting exposure to one odour decreases general reactivity in the olfactory bulb of adult rats. Eur J Neurosci 10: $2472-2475$

Carson KA. 1984. Localization of acetylcholinesterase-positive neurons projecting to the mouse main olfactory bulb. Brain Res Bull 12: 635-639.

Castillo PE, Carleton A, Vincent J-D, Lledo PM. 1999. Multiple and opposing roles of cholinergic transmission in the main olfactory bulb. J Neurosci Nurs 19: 9180-9191.

Chaudhury D, Escanilla O, Linster C. 2009. Bulbar acetylcholine enhances neural and perceptual odor discrimination. J Neurosci 29: 52-60.

Chen WR, Xiong W, Shepherd GM. 2000. Analysis of relations between NMDA receptors and GABA release at olfactory bulb reciprocal synapses. Neuron 25: 625-633.

Ciombor KJ, Ennis M, Shipley MT. 1999. Norepinephrine increases rat mitral cell excitatory responses to weak olfactory nerve input via alpha-1 receptors in vitro. Neuroscience 90: 595-606.

Cohen Y, Reuveni I, Barkai E, Maroun M. 2008. Olfactory learning-induced long-lasting enhancement of descending and ascending synaptic transmission to the piriform cortex. J Neurosci 28: $6664-6669$.

Collins GG, Probett GA, Anson J, McLaughlin NJ. 1984. Excitatory and inhibitory effects of noradrenaline on synaptic transmission in the rat olfactory cortex slice. Brain Res 294: 211-223.

Constanti A, Sim JA. 1987. Muscarinic receptors mediating suppression of the M-current in guinea-pig olfactory cortex neurones may be of the M2-subtype. Br I Pharmacol 90: 3-5.

Coopersmith R, Leon M. 1984. Enhanced neural response to familiar olfactory cues. Science 225: 849-851.

Datiche F, Cattarelli M. 1996. Catecholamine innervation of the piriform cortex: A tracing and immunohistochemical study in the rat. Brain Res 710: $69-78$.

Datiche F, Luppi PH, Cattarelli M. 1995. Serotonergic and non-serotonergic projections from the raphe nuclei to the piriform cortex in the rat: A cholera toxin B subunit (CTb) and 5-HT immunohistochemical study. Brain Res 671: $27-37$

De Olmos J, Heimer L. 1980. Double and triple labeling of neurons with fluorescent substances; the study of collateral pathways in the ascending raphe system. Neurosci Lett 19: 7-12.

De Olmos J, Hardy H, Heimer L. 1978. The afferent connections of the main and the accessory olfactory bulb formations in the rat: An experimental HRP-study. J Comp Neurol 181: 213-244.

De Rosa E, Hasselmo M. 2000. Muscarininc cholinergic neuromodulation reduces proactive interference between stored odor memories during associative learning in rats. Behav Neurosci 114: 32-41.

De Rosa E, Hasselmo ME, Baxter MG. 2001. Contribution of the cholinergic basal forebrain to proactive interference from stored odor memories during associative learning in rats. Behav Neurosci 115: 314-327.

Doty RL, Bagla R, Kim N. 1999. Physostigmine enhances performance on an odor mixture discrimination test. Physiol Behav 65: 801-804

Doucette W, Restrepo D. 2008. Profound context-dependent plasticity of mitral cell responses in olfactory bulb. PLoS Biol 6: e258. doi: 10.1371/ journal.pbio.0060258.

Doucette W, Milder J, Restrepo D. 2007. Adrenergic modulation of olfactory bulb circuitry affects odor discrimination. Learn Mem 14: $539-547$.
Elaagouby A, Ravel N, Gervais R. 1991. Cholinergic modulation of excitability in the rat olfactory bulb: Effect of local application of cholinergic agents on evoked field potentials. Neuroscience 45: 653-662.

Ennis M, Linster C, Aroniadou-Anderjaska V, Ciombor K, Shipley MT. 1998. Glutamate and synaptic plasticity at mammalian primary olfactory synapses. Ann N Y Acad Sci 855: 457-466.

Ennis M, Zhou FM, Ciombor KJ, Aroniadou-Anderjaska V, Hayar A, Borrelli E, Zimmer LA, Margolis F, Shipley MT. 2001. Dopamine D2 receptor-mediated presynaptic inhibition of olfactory nerve terminals. J Neurophysiol 86: 2986-2997.

Escanilla O, Arrellanos A, Karnow A, Ennis M, Linster C. 2010. Noradrenergic modulation of behavioral odor detection and discrimination thresholds in the olfactory bulb. Eur J Neurosci 32: $458-468$.

Fallon JH, Moore RY. 1978. Catecholamine innervation of the basal forebrain. III. Olfactory bulb, anterior olfactory nuclei, olfactory tubercle and piriform cortex. J Comp Neurol 180: 533-544.

Fletcher ML, Wilson DA. 2002. Experience modifies olfactory acuity: Acetylcholine-dependent learning decreases behavioral generalization between similar odorants. J Neurosci 22: pRC201 (1-5).

Fletcher ML, Wilson DA. 2003. Olfactory bulb mitral-tufted cell plasticity: Odorant-specific tuning reflects previous odorant exposure. J Neurosci 23: $6946-6955$.

Fletcher ML, Richter JR, Chen WR. 2009. In vivo optical imaging of experience-induced olfactory bulb glomerular plasticity. Chem Senses 34: pA95. doi: 10.1093/chemse/bjp032.

Freeman WJ, Schneider W. 1982. Changes in spatial patterns of rabbit olfactory EEG with conditioning to odors. Psychophysiology 19: $44-56$.

Funk D, Amir S. 2000. Enhanced fos expression within the primary olfactory and limbic pathways induced by an aversive conditioned odor stimulus. Neuroscience 98: 403-406.

Gellman RL, Aghajanian GK. 1993. Pyramidal cells in piriform cortex receive a convergence of inputs from monoamine activated GABAergic interneurons. Brain Res 600: 63-73.

Ghatpande AS, Sivaraaman K, Vijayaraghavan S. 2006. Store calcium mediates cholinergic effects on mIPSCs in the rat main olfactory bulb. J Neurophysiol 95: 1345-1355.

Gire DH, Schoppa NE. 2008. Long-term enhancement of synchronized oscillations by adrenergic receptor activation in the olfactory bulb. J Neurophysiol 99: 2021-2025.

Gomez C, Brinon JG, Barbado MV, Weruaga E, Valero J, Alonso JR. 2005. Heterogeneous targeting of centrifugal inputs to the glomerular layer of the main olfactory bulb. J Chem Neuroanat 29: 238-254.

Guerin D, Peace ST, Didier A, Linster C, Cleland TA. 2008. Noradrenergic neuromodulation in the olfactory bulb modulates odor habituation and spontaneous discrimination. Behav Neurosci 122: 816-826.

Haberly LB. 2001. Parallel-distributed processing in olfactory cortex: New insights from morphological and physiological analysis of neuronal circuitry. Chem Senses 26: 551-576.

Halasz N, Ljungdahl A, Hokfelt T. 1978. Transmitter histochemistry of the rat olfactory bulb. II. Fluorescence histochemical, autoradiographic and electron microscopic localization of monoamines. Brain Res 154: 253-271.

Hardy A, Palouzier-Paulignan B, Duchamp A, Royet JP, Duchamp-Viret P 2005. 5-Hydroxytryptamine action in the rat olfactory bulb: In vitro electrophysiological patch-clamp recordings of juxtaglomerular and mitral cells. Neuroscience 131: 717-731.

Harley CW, Darby-King A, McCann J, McLean JH. 2006. $\beta 1$-Adrenoceptor or $\alpha 1$-adrenoceptor activation initiates early odor preference learning in rat pups: Support for the mitral cell/cAMP model of odor preference learning. Learn Mem 13: 8-13.

Hasselmo ME. 1995. Neuromodulation and cortical function: Modeling the physiological basis of behavior. Behav Brain Res 67: 1-27.

Hasselmo ME. 1999. Neuromodulation: Acetylcholine and memory consolidation. Trends in Cog Sci 3: 351-359.

Hasselmo ME, Barkai E. 1995. Cholinergic modulation of activity-dependent synaptic plasticity in the piriform cortex and associative memory function in a network biophysical simulation. J Neurosci 15: 6592-6604.

Hasselmo ME, Bower JM. 1992. Cholinergic supression specific to intrinsic not afferent fibers synapses in rat piriform (olfactory) cortex. J Neurophysiol 67: 1222-1229.

Hasselmo ME, Linster C, Patil M, Ma D, Cekic M. 1997. Noradrenergic suppression of synaptic transmission may influence cortical signal-to-noise ratio. J Neurophysiol 77: 3326-3339.

Hayar A, Heyward PM, Heinbockel T, Shipley MT, Ennis M. 2001. Direct excitation of mitral cells via activation of $\alpha 1$-noradrenergic receptors in rat olfactory bulb slices. J Neurophysiol 86: 2173-2182.

Hunter AJ, Murray TK. 1989. Cholinergic mechanisms in a simple test of olfactory learning in the rat. Psychoparmacology 99: 270-275. 
Ichikawa T, Hirata Y. 1986. Organization of choline acetyltransferasecontaining structures in the forebrain of the rat. J Neurosci 6: $281-292$.

Isaacson JS, Strowbridge BW. 1998. Olfactory reciprocal synapses: Dendritic signaling in the CNS. Neuron 20: 749-761.

Ishida Y, Hashiguchi H, Takeda R, Ishizuka Y, Mitsuyama Y, Kannan H, Nishimori T, Nakahara D. 2002. Conditioned-fear stress increases Fos expression in monoaminergic and GABAergic neurons of the locus coeruleus and dorsal raphe nuclei. Synapse 45: 46-51.

Jahr CE, Nicoll RA. 1982. An intracellular analysis of dendrodendritic inhibition in the turtle in vitro olfactory bulb. J Physiol 326: 213-234.

Jiang M, Griff ER, Ennis M, Zimmer LA, Shipley MT. 1996. Activation of locus coeruleus enhances the responses of olfactory bulb mitral cells to weak olfactory nerve input. J Neurosci 16: 6319-6329.

Johnson BA, Woo CC, Duong H, Nguyen V, Leon M. 1995. A learned odor evokes an enhanced Fos-like glomerular response in the olfactory bulb of young rats. Brain Res 699: 192-200.

Jung MW, Larson J, Lynch G. 1990. Long-term potentiation of monosynaptic EPSPs in rat piriform cortex in vitro. Synapse 6: 279-283.

Kanter ED, Haberly LB. 1990. NMDA-dependent induction of long-term potentiation in afferent and association fiber systems of piriform cortex in vitro. Brain Res 525: 175-179.

Kasa P, Hlavati I, Dobo E, Wolff A, Joo F, Wolff JR. 1995. Synaptic and non-synaptic cholinergic innervation of the various types of neurons in the main olfactory bulb of adult rat: Immunocytochemistry of choline acetyltransferase. Neuroscience 67: 667-677.

Kay LM, Laurent G. 1999. Odor- and context-dependent modulation of mitral cell activity in behaving rats. Nat Neurosci 2: 1003-1009.

Kendrick KM, Levy F, Keverne EB. 1992. Changes in the sensory processing of olfactory signals induced by birth in sheep. Science 256: 833-836.

Keverne EB, Brennan PA. 1996. Olfactory recognition memory. J Physiol Paris 90: $399-401$.

King MV, Marsden CA, Fone KC. 2008. A role for the 5-HT(1A), 5-HT(4) and 5-HT(6) receptors in learning and memory. Trends Pharmacol Sci 29: $482-492$.

Knafo S, Grossman Y, Barkai E, Benshalom G. 2001. Olfactory learning is associated with increased spine density along apical dendrites of pyramidal neurons in the rat piriform cortex. Eur J Neurosci 13: $633-638$.

Kroon JA, Carobrez AP. 2009. Olfactory fear conditioning paradigm in rats: Effects of midazolam, propranolol or scopolamine. Neurobiol Learn Mem 91: $32-40$.

Kunze WA, Shafton AD, Kemm RE, McKenzie JS. 1991. Effect of stimulating the nucleus of the horizontal limb of the diagonal band on single unit activity in the olfactory bulb. Neuroscience 40: 21-27.

Langdon PE, Harley CW, McLean JH. 1997. Increased beta adrenoceptor activation overcomes conditioned olfactory learning deficits induced by serotonin depletion. Brain Res Dev Brain Res 102: 291-293.

Le Jeune H, Jourdan F. 1993. Cholinergic innervation of olfactory glomeruli in the rat: An ultrastructural immunocytochemical study. J Comp Neurol 336: 279-292.

Letty S, Child R, Dumuis A, Pantaloni A, Bockaert J, Rondouin G. 1997. 5-HT4 receptors improve social olfactory memory in the rat. Neuropharmacology 36: 681-687.

Levy F, Gervais R, Kindermann U, Orgeur P, Piketty V. 1990. Importance of $\beta$-noradrenergic receptors in the olfactory bulb of sheep for recognition of lambs. Behav Neurosci 104: 464-469.

Levy F, Richard P, Meurisse M, Ravel N. 1997. Scopolamine impairs the ability of parturient ewes to learn to recognise their lambs. Psychopharmacology 129: 85-90.

Linster C, Cleland TA. 2002. Cholinergic modulation of sensory representations in the olfactory bulb. Neural Netw 15: 709-717.

Linster C, Hasselmo ME. 2000. Neural activity in the horizontal limb of the diagonal band of Broca can be modulated by electrical stimulation of the olfactory bulb and cortex in rats. Neurosci Lett 282: $157-160$.

Linster C, Hasselmo ME. 2001. Neuromodulation and the functional dynamics of piriform cortex. Chem Senses 26: 585-594.

Linster C, Wyble BP, Hasselmo ME. 1999. Electrical stimulation of the horizontal limb of the diagonal band of Broca modulates population EPSPs in piriform cortex. J Neurophysiol 81: 2737-2742.

Linster C, Garcia PA, Hasselmo ME, Baxter MG. 2001. Selective loss of cholinergic neurons projecting to the olfactory system increases perceptual generalization between similar, but not dissimilar, odorants. Behav Neurosci 115: 826-833.

Linster C, Johnson BA, Morse A, Yue E, Leon M. 2002. Spontaneous versus reinforced olfactory discriminations. J Neurosci 22: 6842-6845.

Litaudon P, Mouly AM, Sullivan R, Gervais R, Cattarelli M. 1997. Learning-induced changes in rat piriform cortex activity mapped using multisite recording with voltage sensitive dye. Eur J Neurosci 9: 1593-1602.
Loughlin SE, Foote SL, Fallon JH. 1982. Locus coeruleus projections to cortex: Topography, morphology and collateralization. Brain Res Bull 9: $287-294$.

Lowry CA, Johnson PL, Hay-Schmidt A, Mikkelsen J, Shekhar A. 2005. Modulation of anxiety circuits by serotonergic systems. Stress 8: 233-246.

Luskin MB, Price JL. 1982. The distribution of axon collaterals from the olfactory bulb and the nucleus of the horizontal limb of the diagonal band to the olfactory cortex, demonstrated by double retrograde labeling techniques. J Comp Neurol 209: 249-263.

Lysakowski A, Wainer BH, Bruce G, Hersh LB. 1989. An atlas of the regional and laminar distribution of choline acetyltransferase immunoreactivity in rat cerebral cortex. Neuroscience 28: 291-336.

Macrides F, Davis BJ, Youngs WM, Nadi NS, Margolis FL. 1981. Cholinergic and catecholaminergic afferents to the olfactory bulb in the hamster: A neuroanatomical, biochemical, and histochemical investigation. J Comp Neurol 203: 495-514.

Mandairon N, Ferretti CJ, Stack CM, Rubin DB, Cleland TA, Linster C. 2006. Cholinergic modulation in the olfactory bulb influences spontaneous olfactory discrimination in adult rats. Eur J Neurosci 24: 3234-3244.

Mandairon N, Didier A, Linster C. 2008a. Odor enrichment increases interneurons responsiveness in spatially defined regions of the olfactory bulb correlated with perception. Neurobiol Learn Mem 90: $178-184$.

Mandairon N, Peace S, Karnow A, Kim J, Ennis M, Linster C. 2008b. Noradrenergic modulation in the olfactory bulb influences spontaneous and reward-motivated discrimination, but not the formation of habituation memory. Eur I Neurosci 27: 1210-1219.

Marchetti E, Dumuis A, Bockaert J, Soumireu-Mourat B, Roman FS. 2000. Differential modulation of the 5-HT(4) receptor agonists and antagonist on rat learning and memory. Neuropharmacology 39: 2017-2027.

Marek GJ, Aghajanian GK. 1996. Alpha 1B-adrenoceptor-mediated excitation of piriform cortical interneurons. Eur J Pharmacol 305: 95-100.

Martin C, Gervais R, Hugues E, Messaoudi B, Ravel N. 2004. Learning modulation of odor-induced oscillatory responses in the rat olfactory bulb: A correlate of odor recognition? J Neurosci 24: 389-397.

McLean JH, Shipley MT. 1987. Serotonergic afferents to the rat olfactory bulb: I. Origins and laminar specificity of serotonergic inputs in the adult rat. J Neurosci 7: 3016-3028.

McLean JH, Shipley MT, Nickell WT, Aston-Jones G, Reyher CK. 1989. Chemoanatomical organization of the noradrenergic input from locus coeruleus to the olfactory bulb of the adult rat. J Comp Neurol 285: 339-349.

McLean JH, Darby-King A, Sullivan RM, King SR. 1993. Serotonergic influence on olfactory learning in the neonate rat. Behav Neural Biol 60: $152-162$.

McLean JH, Darby-King A, Hodge E. 1996. 5-HT2 receptor involvement in conditioned olfactory learning in the neonate rat pup. Behav Neurosci 110: $1426-1434$.

McLennan H. 1971. The pharmacology of inhibition of mitral cells in the olfactory bulb. Brain Res 29: $177-184$.

Miranda MI, Ortiz-Godina F, Garcia D. 2009. Differential involvement of cholinergic and beta-adrenergic systems during acquisition, consolidation, and retrieval of long-term memory of social and neutral odors. Behav Brain Res 202: 19-25.

Montag-Sallaz M, Buonviso N. 2002. Altered odor-induced expression of c-fos and arg 3.1 immediate early genes in the olfactory system after familiarization with an odor. J Neurobiol 52: 61-72.

Monti JM, Jantos H. 2008. The roles of dopamine and serotonin, and of their receptors, in regulating sleep and waking. Prog Brain Res 172: 625-646.

Moriceau S, Sullivan RM. 2004. Unique neural circuitry for neonatal olfactory learning. J Neurosci 24: 1182-1189.

Moriizumi T, Tsukatani T, Sakashita H, Miwa T. 1994. Olfactory disturbance induced by deafferentation of serotonergic fibers in the olfactory bulb. Neuroscience 61: 733-738.

Mouly AM, Elaagouby A, Ravel N. 1995. A study of the effects of noradrenaline in the rat olfactory bulb using evoked field potential response. Brain Res 681: 47-57.

Murphy GJ, Darcy DP, Isaacson JS. 2005. Intraglomerular inhibition: Signaling mechanisms of an olfactory microcircuit. Nat Neurosci 8: $354-364$.

Mutoh H, Yuan Q, Knopfel T. 2005. Long-term depression at olfactory nerve synapses. J Neurosci 25: 4252-4259.

Nai Q, Dong HW, Hayar A, Linster C, Ennis M. 2009. Noradrenergic regulation of GABAergic inhibition of main olfactory bulb mitral cells varies as a function of concentration and receptor subtype. Neurophysiol 101: 2472-2484. 
Nai Q, Dong HW, Linster C, Ennis M. 2010. Activation of $\alpha 1$ and $\alpha 2$ noradrenergic receptors exert opposing effects on excitability of main olfactory bulb granule cells. Neuroscience 169: 882-892.

Nickell WT, Shipley MT. 1988a. Two anatomically specific classes of candidate cholinoceptive neurons in the rat olfactory bulb. J Neurosci 8: $4482-4491$.

Nickell WT, Shipley MT. 1988b. Neurophysiology of magnocellular forebrain inputs to the olfactory bulb in the rat: Frequency potentiation of field potentials and inhibition of output neurons. J Neurosci 8: 4492-4502.

Pandipati S, Gire DH, Schoppa NE. 2010. Adrenergic receptor-mediated disinhibition of mitral cells triggers long-term enhancement of synchronized oscillations in the olfactory bulb. J Neurophysiol 104: 665-674.

Paolini AG, McKenzie JS. 1993. Effects of lesions in the horizontal diagonal band nucleus on olfactory habituation in the rat. Neuroscience 57: 717-724.

Patil MM, Linster C, Lubenov E, Hasselmo ME. 1998. Cholinergic agonist carbachol enables associative long-term potentiation in piriform cortex slices. J Neurophysiol 80: 2467-2474.

Perio A, Terranova JP, Worms P, Bluthe RM, Dantzer R, Biziere K. 1989. Specific modulation of social memory in rats by cholinomimetic and nootropic drugs, by benzodiazepine inverse agonists, but not by psychostimulants. Psychopharmacology 97: 262-268.

Petzold GC, Hagiwara A, Murthy VN. 2009. Serotonergic modulation of odor input to the mammalian olfactory bulb. Nat Neurosci 12: $784-791$.

Pieribone VA, Nicholas AP, Dagerlind A, Hokfelt T. 1994. Distribution of alpha 1 adrenoceptors in rat brain revealed by in situ hybridization experiments utilizing subtype-specific probes. J Neurosci 14: 4252-4268.

Pignatelli A, Belluzzi O. 2008. Cholinergic modulation of dopaminergic neurons in the mouse olfactory bulb. Chem Senses 33: 331-338.

Pompeiano M, Palacios JM, Mengod G. 1992. Distribution and cellular localization of mRNA coding for 5-HT1A receptor in the rat brain: Correlation with receptor binding. J Neurosci 12: 440-453.

Pompeiano M, Palacios JM, Mengod G. 1994. Distribution of the serotonin 5-HT2 receptor family mRNAs: Comparison between 5-HT2A and 5-HT2C receptors. Brain Res Mol Brain Res 23: 163-178.

Pressler R, Strowbridge BW. 2007. Blanes cells mediate persistent feedforward inhibition onto granule cells in the olfactory bulb. Neuron 49: $889-904$.

Pressler RT, Inoue T, Strowbridge BW. 2007. Muscarinic receptor activation modulates granule cell excitability and potentiates inhibition onto mitral cells in the rat olfactory bulb. J Neurosci 27: 10969-10981.

Rangel S, Leon M. 1995. Early odor preference training increases olfactory bulb norepinephrine. Brain Res Dev Brain Res 85: 187-191.

Ravel N, Akaoka H, Gervais R, Chouvet G. 1990. The effect of acetylcholine on rat olfactory bulb unit activity. Brain Res Bull 24: 151-155.

Ravel N, Vigouroux M, Elaagouby A, Gervais R. 1992. Scopolamine impairs delayed matching in an olfactory task in rats. Psychopharmacology 109: 439-443.

Ravel N, Elaagouby A, Gervais R. 1994. Scopolamine injection into the olfactory bulb impairs short-term olfactory memory in rats. Behav Neurosci 108: 317-324.

Ravel N, Chabaud P, Martin C, Gaveau V, Hugues E, Tallon-Baudry C, Bertrand O, Gervais R. 2003. Olfactory learning modifies the expression of odour-induced oscillatory responses in the gamma $(60-90 \mathrm{~Hz})$ and beta $(15-40 \mathrm{~Hz})$ bands in the rat olfactory bulb. Eur J Neurosci 17: $350-358$.

Rochefort C, Gheusi G, Vincent JD, Lledo PM. 2002. Enriched odor exposure increases the number of newborn neurons in the adult olfactory bulb and improves odor memory. J Neurosci 22: 2679-2689.

Roman F, Staubli U, Lynch G. 1987. Evidence for synaptic potentiation in a cortical network during learning. Brain Res 418: 221-226.

Roman FS, Chaillan FA, Soumireu-Mourat B. 1993a. Long-term potentiation in rat piriform cortex following discrimination learning. Brain Res 601: $265-272$.

Roman FS, Simonetto I, Soumireu-Mourat B. 1993b. Learning and memory of odor-reward association: Selective impairment following horizontal diagonal band lesions. Behav Neurosci 107: 72-81.

Saar D, Grossman Y, Barkai E. 2001. Long-lasting cholinergic modulation underlies rule learning in rats. J Neurosci 21: $1385-1392$.

Saar D, Grossman Y, Barkai E. 2002. Learning-induced enhancement of postsynaptic potentials in pyramidal neurons. J Neurophysiol 87: $2358-2363$.

Salcedo E, Zhang C, Kronberg E, Restrepo D. 2005. Analysis of training-induced changes in ethyl acetate odor maps using a new computational tool to map the glomerular layer of the olfactory bulb. Chem Senses 30: 615-626.

Salmoiraghi GC, Bloom FE, Costa E. 1964. Adrenergic mechanisms in rabbit olfactory bulb. Am J Physiol 207: 1417-1424.
Sara SJ. 2009. The locus coeruleus and noradrenergic modulation of cognition. Nat Rev Neurosci 10: 211-223.

Sara SJ, Vankov A, Herve A. 1994. Locus coeruleus-evoked responses in behaving rats: a clue to the role of noradrenaline in memory. Brain Res Bull 35: $457-465$.

Shea SD, Katz LC, Mooney R. 2008. Noradrenergic induction of odor-specific neural habituation and olfactory memories. J Neurosci $\mathbf{2 8}$ : 10711-10719.

Sheldon PW, Aghajanian GK. 1990. Serotonin (5-HT) induces IPSPs in pyramidal layer cells of rat piriform cortex: evidence for the involvement of a 5-HT2-activated interneuron. Brain Res 506: $62-69$.

Sheldon PW, Aghajanian GK. 1991. Excitatory responses to serotonin (5-HT) in neurons of the rat piriform cortex: evidence for mediation by 5 -HT1C receptors in pyramidal cells and 5-HT2 receptors in interneurons. Synapse 9: 208-218.

Shepherd GM, Chen WR, Greer CA. 2004. Olfactory bulb. In The synaptic organization of the brain, 5th edition (ed. GM Shepherd), 165-216. Oxford University Press, New York.

Shipley MT, Adamek GD. 1984. The connections of the mouse olfactory bulb: A study using orthograde and retrograde transport of wheat germ agglutinin conjugated to horseradish peroxidase. Brain Res Bull 12: 669-688.

Shipley MT, Ennis M. 1996. Functional organization of olfactory system. I Neurobiol 30: $123-176$.

Shipley MT, Halloran FJ, Torre JDL. 1985. Surprisingly rich projection from locus coeruleus to the olfactory bulb in the rat. Brain Res 329: 294-299.

Shute CC, Lewis PR. 1967. The ascending cholinergic reticular system: Neocortical, olfactory and subcortical projections. Brain 90: 497-520.

Smith JJ, Shionoya K, Sullivan RM, Wilson DA. 2009. Auditory stimulation dishabituates olfactory responses via noradrenergic cortical modulation. Neural Plast 2009: 754014. doi: 10.1155/2009/754014.

Stripling JS, Patneau DK, Gramlich CA. 1988. Selective long-term potentiation in the pyriform cortex. Brain Res 441: 281-291.

Sullivan RM, Wilson DA, Leon M. 1989. Norepinephrine and learning-induced plasticity in infant rat olfactory system. J Neurosci 9: 3998-4006.

Sullivan RM, Zyzak DR, Skierkowski P, Wilson DA. 1992. The role of olfactory bulb norepinephrine in early olfactory learning. Brain Res Dev Brain Res 70: 279-282.

Sullivan RM, Stackenwalt G, Nasr F, Lemon C, Wilson DA. 2000. Association of an odor with activation of olfactory bulb noradrenergic $\beta$-receptors or locus coeruleus stimulation is sufficient to produce learned approach responses to that odor in neonatal rats. Behav Neurosci 114: $957-962$.

Trombley PQ, Shepherd GM. 1992. Noradrenergic inhibition of synaptic transmission between mitral and granule cells in mammalian olfactory bulb cultures. I Neurosci 12: 3985-3991.

Tseng GF, Haberly LB. 1989. Deep neurons in piriform cortex. II. Membrane properties that underlie unusual synaptic responses. J Neurophysiol 62: 386-400.

Veyrac A, Sacquet J, Nguyen V, Marien M, Jourdan F, Didier A. 2009. Novelty determines the effects of olfactory enrichment on memory and neurogenesis through noradrenergic mechanisms. Neuropsychopharmacology 34: 786-795.

Vucinic D, Cohen LB, Kosmidis EK. 2006. Interglomerular center-surround inhibition shapes odorant-evoked input to the mouse olfactory bulb in vivo. J Neurophysiol 95: 1881-1887.

Wachowiak M, McGann JP, Heyward PM, Shao Z, Puche AC, Shipley MT. 2005. Inhibition of olfactory receptor neuron input to olfactory bulb glomeruli mediated by suppression of presynaptic calcium influx. J Neurophysiol 94: 2700-2712.

Weinberger NM, Bakin JS. 1998. Learning-induced physiological memory in adult primary auditory cortex: Receptive fields plasticity, model, and mechanisms. Audiol Neuro-otol 3: 145-167.

Wilson D. 2001. Scopolamine enhances generalization between odor representations in the rat olfactory cortex. Learn Mem 8: 279-285.

Wilson DA, Leon M. 1988a. Noradrenergic modulation of olfactory bulb excitability in the postnatal rat. Brain Res 470: 69-75.

Wilson DA, Leon M. 1988b. Spatial patterns of olfactory bulb single-unit responses to learned olfactory cues in young rats. J Neurophysiol 59: $1770-1782$.

Wilson DA, Sullivan RM. 1992. Blockade of mitral/tufted cell habituation to odors by association with reward: A preliminary note. Brain Res 594: $143-145$.

Wilson DA, Sullivan RM. 1994. Neurobiology of associative learning in the neonate: Early olfactory learning. Behav Neural Biol 61: 1-18.

Winslow JT, Camacho F. 1995. Cholinergic modulation of a decrement in social investigation following repeated contacts between mice. Psychopharmacology 121: 164-172. 
Wirth S, Lehmann O, Bertrand F, Lazarus C, Jeltsch H, Cassel JC. 2000. Preserved olfactory short-term memory after combined cholinergic and serotonergic lesions using 192 IgG-saporin and

5,7-dihydroxytryptamine in rats. Neuroreport 11: 347-350.

Woo CC, Leon M. 1995. Distribution and development of beta-adrenergic receptors in the rat olfactory bulb. J Comp Neurol $\mathbf{3 5 2}$ $1-10$.

Woo CC, Oshita MH, Leon M. 1996. A learned odor decreases the number of Fos-immunopositive granule cells in the olfactory bulb of young rats. Brain Res 716: 149-156.

Woo CC, Hingco EE, Taylor GE, Leon M. 2006. Exposure to a broad range of odorants decreases cell mortality in the olfactory bulb. Neuroreport 17: 817-821.

Woo CC, Hingco EE, Johnson BA, Leon M. 2007. Broad activation of the glomerular layer enhances subsequent olfactory responses. Chem Senses 32: $51-55$.

Woolf NJ, Eckenstein F, Butcher LL. 1984. Cholinergic systems in the rat brain: I. projections to the limbic telencephalon. Brain Res Bull 13: $751-784$.

Wright BA, Fitzgerald MB. 2001. Different patterns of human discrimination learning for two interaural cues to sound-source location. Proc Natl Acad Sci 98: 12307-12312.

Yokoi M, Mori K, Nakanishi S. 1995. Refinement of odor molecule tuning by dendrodendritic synaptic inhibition in the olfactory bulb. Proc Natl Acad Sci 92: 3371-3375.

Young A, Sun QQ. 2007. Long-term modifications in the strength of excitatory associative inputs in the piriform cortex. Chem Senses 32: $783-794$.
Yuan Q, Harley CW, Bruce JC, Darby-King A, McLean JH. 2000. Isoproterenol increases CREB phosphorylation and olfactory nerve-evoked potentials in normal and 5-HT-depleted olfactory bulbs in rat pups only at doses that produce odor preference learning. Learn Mem 7: 413-421.

Yuan Q, Harley CW, McLean JH, Knopfel T. 2002. Optical imaging of odor preference memory in the rat olfactory bulb. J Neurophysiol 87: 3156-3159.

Yuan Q, Harley CW, McLean JH. 2003a. Mitral cell $\beta 1$ and 5-HT2A receptor colocalization and cAMP coregulation: A new model of norepinephrine-induced learning in the olfactory bulb. Learn Mem 10: $5-15$.

Yuan Q, Harley CW, Darby-King A, Neve RL, McLean JH. 2003b. Early odor preference learning in the rat: Bidirectional effects of cAMP response element-binding protein (CREB) and mutant CREB support a causal role for phosphorylated CREB. J Neurosci 23: 4760-4765.

Zaborszky L, Carlsen J, Brashear HR, Heimer L. 1986. Cholinergic and GABAergic afferents to the olfactory bulb in the rat with special emphasis on the projection neurons in the nucleus of the horizontal limb of the diagonal band. J Comp Neurol 243: $488-509$.

Zimmer LA, Ennis M, Shipley MT. 1999. Diagonal band stimulation increases piriform cortex neuronal excitability in vivo. Neuroreport 10: $2101-2105$.

Received July 18, 2010; accepted in revised form August 31, 2010. 


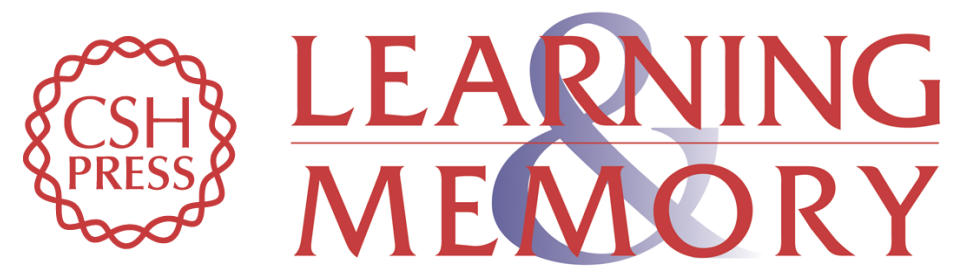

\section{Neural correlates of olfactory learning: Critical role of centrifugal neuromodulation}

Max L. Fletcher and Wei R. Chen

Learn. Mem. 2010, 17:

Access the most recent version at doi:10.1101//m.941510

References This article cites 184 articles, 36 of which can be accessed free at:

http://learnmem.cshlp.org/content/17/11/561.full.html\#ref-list-1

License

Email Alerting Receive free email alerts when new articles cite this article - sign up in the box at the Service top right corner of the article or click here. 